\title{
Postural Assessment of Women Workers Involved in Various Handloom Activities
}

\author{
Geetashree Bori* and Nandita Bhattacharyya
}

Department of Family Resource Management and Consumer Science, College of Community

Science, Assam Agricultural University, Jorhat-785013, Assam, India

*Corresponding author

Keywords

Ergonomics,

Handloom

activities,

Handloom weaving,

Posture, Weavers,

Women workers

Article Info

Accepted:

24 September 2020

Available Online:

10 October 2020

\section{A B S T R A C T}

Women workers are involved in various activities in handloom industries starting from spinning to weaving. While performing these activities they require to maintain some postures for a long period with high postural load due to constraining of work method and working condition and in the long run result in the overusing of muscles, tendons, joints, and nerves. According to the fourth handloom census (2019-20), 91.8 percent of women workers of Assam are involved in weaving and allied activities. This unnatural posture if maintained for a long period, the workers may experience health-related problems, leading to reduce productivity and early retirement. Therefore, to improve their working condition and enhance the performance of work there is a need to assess their working posture involved in various handloom activities. The present study was undertaken to assess the working posture of women workers involved in various handloom activities. Data were collected by interview method, photography, video recording, and observation of work practices. A total of 60 workers were taken for the study from Lakhimpur district of Assam. The postural assessment was done by using ergonomic tools: RULA and Strain Index. Awkward postures were observed in the handloom workers. The mean RULA score was found highest in weaving activity with $6.41 \pm 0.49$ followed by warping, spinning. Strain Index was found highest in the right hand and left hand of weaving activity. The high occupational risk was found in the handloom activities. Therefore the application of ergonomics would help in reducing postural exertion.

\section{Introduction}

The large workforce employed in industries and many other occupations comprise of women. In Assam, handloom weaving can be found predominantly engaged by the women weavers in rural areas and some parts of the state. Nearly, 91.8 percent of women workers of Assam are involved in weaving and allied activities (Fourth all India Handloom census 2019-20). Moreover, handloom weaving offers livelihood opportunities to many women workers and helps them to do their job along with their domestic responsibilities. In particular, the weaver gets involve in various handloom activities starting from spinning, winding, twisting, warping, threading the healds, and threading the reeds, 
setting the warp on the loom, preparing the loom for weaving, and finally weaving on the loom. Additionally, in the whole weaving process, the weavers also spent time on their loom in different postures as sitting, standing, and sometimes squatting on the floor while performing the handloom activities. These activities when performed, the workers assume some awkward and unnatural postures due to task demand without giving considerations to their individual capacity and limitations. Furthermore, overtime these unnatural postures are likely to develop stress and trauma that the workers experience resulting in a risk to health (Nag et al., 2010; Dewangan and Sora, 2015).

Posture is a relative arrangement of bodily parts, more specifically the orientation of limbs, trunk, and head during work. Regarding working posture, the movement of the bodily segment depends on the demands driving for the task, workstation design, and machine layout.Several studies have shown that poor working postures have many healthrelated impacts and in the long run, might cause health-related issues as musculoskeletal problems (Nag et al., 2010; Dewangan and Sora 2015; Chantaramanee et al 2015; Choobineh et al., 2007).

Workers engaged in various handloom activities perform with high postural load due to constrains of work method and working condition in a static posture, the repetitive task is risk factors for the work-related musculoskeletal disorder (Banerjee and Gangopandyay, 2003; Pandit et al., 2013; Borah and Kalita, 2016). Therefore, these problems if ignored may lead to body deformities and debilitate them which might indirectly affect the work performance, production of their earnings, and livelihood. Hence, the present study was undertaken to assess the working posture of women workers involved in various handloom activities.

\section{Materials and Methods}

\section{Selection of workers}

To select the workers a multistage sampling design was used. Two sub-division of the Lakhimpur district of Assam was selected due to the large involvement of workers in handloom production in these areas. For the present study, the handloom workers were selected through a list of registered handloom weaving units under PWCS and Self Help Groups (SHGs). A total of 60 workers, engaged in handloom weaving were selected purposively. Each participant in the study was interviewed and the activities were observed.

The ergonomic tools used were RULA and SI. RULA (Rapid Upper Limb Assessment) was used to evaluate the working posture, force, and movement (McAtamney and Corlett, 1993) associated with handloom activities. SI (Strain Index) to evaluate the task risk factors for developing work-related musculoskeletal disorders of the distal upper extremities (hand, wrist, and elbow). Six task variables were used to describe the exertion levels through rating values: the intensity of exertion, duration of exertion, efforts per minute, hand/wrist posture, speed of work, and duration per day in hours (Moore and Garg, 1995). Photography and video recording of workers while performing the handloom activities were taken for reviewing on-site findings. Pregnant, lactating, and handloom workers having chronic ailments and physical deformity were excluded from the study.

Data were collected using a questionnaire based on the following: (a) Extend of involvement of the workers. (b) Postural analysis of the workers. (c) Assessment of RULA in different handloom activities (d) Assessment of SI (strain index) of the workers. 


\section{Statistical analysis}

Frequency, percentage, mean, standard deviation, weighted score, rank, and paired ttest to analyse the difference between the left hand and right hand, were worked out for different parameters, and data were interpreted by using SPSS version 20.0 statistical package program.

\section{Results and Discussion}

Postures adopted in handloom weaving while performing different weaving activities were assessed by extend of involvement, the posture assumed while working, and analysis of posture using RULA, SI, and by observation of work practices.

\section{Extend of involvement of the workers}

The women weavers were highly involved in various handloom activities starting from Spinning, winding, twisting, warping, threading the healds, threading the reeds, setting the warp on the loom, preparing the loom for weaving, and finally weaving in the loom. Table 1 shows that the participation was studied in terms of the extent of involvement of various handloom activities, to the extent of daily, sometimes, and rarely were scored as 3,2 , and 1 .

After the calculation of the weighted score, the ranking was done accordingly for the different activities. From the table, it was evident that women workers were highly involved in weaving as compared to the other activities and followed by spinning.

The study reveals that the activities as winding and twisting, warping, threading the healds, and threading the reeds, setting the warp on the loom, and preparing the loom for weaving are done sometimes and rarely. These activities are done before weaving, so when a set of weaving warp is completed the workers prepare for another set of warp for weaving.

\section{Postural analysis of the worker}

Handloom workers adopt various postures while performing activities. The analysis of the postures demonstrates that women workers assume a variety of abnormal postures at work. Table 2 and figure 1 revealed that sitting with slight forward bending flexion at the neck and the back with the movement of both hands and legs was assumed by the majority of the worker while performing the weaving activity.

Postures with elbow flexion of the right hand, abduction, and adduction of the fingers, wrist flexed and pronated of the left hand, raised shoulder abduction, and shoulder flexion while weaving were found among the workers.

\section{Assessment of RULA in different Handloom activities}

The RULA (Rapid Upper Limb Assessment) score analysis evaluates the posture and musculoskeletal risk associated with the various handloom activities. Table 3 shows that the RULA score was highest in weaving with a mean and SD value of $6.41 \pm 0.49$ followed by warping, spinning, preparing the loom for weaving, and setting the warp for the loom.

This activity scores between 5-6 and the action level are 3 which indicates that investigation and changes are required soon as shown in table 4. The other activities as winding and twisting, threading the healds, and threading the reeds scores 3-4 which indicates that changes may be required with further investigation. 
Table.1 Involvement of the respondents according to different handloom activities $(n=180)$

\begin{tabular}{|l|l|l|l|l|l|}
\hline \multirow{2}{*}{ Weaving activities } & \multicolumn{2}{|l|}{ Extend of Involvement } & $\begin{array}{l}\text { Weighted } \\
\text { Score }\end{array}$ & Rank \\
\cline { 2 - 5 } & Daily(3) & Sometimes(2) & Rarely(1) & II \\
\hline Spinning & $\begin{array}{l}32 \\
(53.3)\end{array}$ & $\begin{array}{l}19 \\
(31.66)\end{array}$ & $\begin{array}{l}9 \\
(15)\end{array}$ & 143 & III \\
\hline $\begin{array}{l}\text { Windingand } \\
\text { Twisting }\end{array}$ & - & $\begin{array}{l}28 \\
(46.66)\end{array}$ & $\begin{array}{l}32 \\
(53.33)\end{array}$ & 88 & IV \\
\hline Warping & - & $\begin{array}{l}25 \\
(41.66)\end{array}$ & $\begin{array}{l}35 \\
(58.33)\end{array}$ & 85 & VI \\
\hline $\begin{array}{l}\text { Threading the } \\
\text { healds }\end{array}$ & - & $\begin{array}{l}21 \\
(35)\end{array}$ & $\begin{array}{l}39 \\
(65)\end{array}$ & 81 & V \\
\hline $\begin{array}{l}\text { Threading the } \\
\text { reeds }\end{array}$ & - & $\begin{array}{l}24 \\
(40)\end{array}$ & $\begin{array}{l}36 \\
(60)\end{array}$ & 84 & VII \\
\hline $\begin{array}{l}\text { Setting the warp on } \\
\text { the loom }\end{array}$ & - & $\begin{array}{l}17 \\
(28.33)\end{array}$ & $\begin{array}{l}43 \\
(71.66)\end{array}$ & 77 & VI \\
\hline $\begin{array}{l}\text { Preparing the loom } \\
\text { for weaving }\end{array}$ & - & $\begin{array}{l}21 \\
(35)\end{array}$ & $\begin{array}{l}39 \\
(65)\end{array}$ & 81 & I \\
\hline \begin{tabular}{l} 
Weaving \\
\hline
\end{tabular} & $\begin{array}{l}60 \\
(100)\end{array}$ & - & - & 180 & \\
\hline
\end{tabular}

Figures in the parentheses indicates percentage

Table.2 Analysis of different postures assumed by of the respondents in performing different handloom activities

\begin{tabular}{|c|c|c|}
\hline $\begin{array}{l}\text { Weaving } \\
\text { activities }\end{array}$ & Types of postures & Description \\
\hline Spinning & Sitting & $\begin{array}{l}\text { The worker sits in slight bending in forward position on } \\
\text { a pirah with right hand rotating the spinning wheel and } \\
\text { left hand extended to hold the thread of the bobbin }\end{array}$ \\
\hline $\begin{array}{l}\text { Winding and } \\
\text { twisting }\end{array}$ & $\begin{array}{l}\text { Standing } \\
\text { bending }\end{array}$ & $\begin{array}{l}\text { The worker stands in forward bending posture with } \\
\text { arms outstretch to fit the bobbin. }\end{array}$ \\
\hline Warping & $\begin{array}{l}\text { Standing and slight } \\
\text { bending }\end{array}$ & $\begin{array}{l}\text { The worker stand with slight forward bending to rotate } \\
\text { the drum with both the hand }\end{array}$ \\
\hline $\begin{array}{l}\text { Threading the } \\
\text { healds }\end{array}$ & Sitting & $\begin{array}{l}\text { The worker sits in forward bending position with hands } \\
\text { out stretched for threading the healds. }\end{array}$ \\
\hline $\begin{array}{l}\text { Threading the } \\
\text { reeds }\end{array}$ & Sitting & $\begin{array}{l}\text { The worker sits in forward bending position with hands } \\
\text { outstretched for threading the reeds. }\end{array}$ \\
\hline $\begin{array}{l}\text { Setting the } \\
\text { warp on the } \\
\text { loom }\end{array}$ & $\begin{array}{l}\text { Standing } \\
\text { bending }\end{array}$ & $\begin{array}{l}\text { The worker stands with forward bending position } \\
\text { facing downward and is rotating the iron rod of the } \\
\text { beam with both the hands. }\end{array}$ \\
\hline $\begin{array}{l}\text { Preparing the } \\
\text { loom } \\
\text { weaving }\end{array}$ & Squatting & $\begin{array}{l}\text { The worker sits in squatting posture on the ground in } \\
\text { forward bending position and the hands outstretched to } \\
\text { tie the rope in the treadle. }\end{array}$ \\
\hline Weaving & $\begin{array}{l}\text { Sitting on a plank or } \\
\text { bench }\end{array}$ & $\begin{array}{l}\text { The worker sits in forward bending position throwing } \\
\text { the shuttle to and fro. }\end{array}$ \\
\hline
\end{tabular}


Table.3 Mean RULA score of the respondent in various handloom activities

\begin{tabular}{|l|l|}
\hline Weaving activities & RULA scores \\
\hline Spinning & $5.90 \pm 1.42$ \\
\hline Winding and twisting & $4.50 \pm 0.96$ \\
\hline Warping & $6.00 \pm 0.82$ \\
\hline Threading the healds & $4.46 \pm 0.74$ \\
\hline Threading the reeds & $4.38 \pm 1.27$ \\
\hline Setting the warp on the loom & $5.03 \pm 1.30$ \\
\hline Preparing the loom for weaving & $5.75 \pm 1.05$ \\
\hline Weaving & $6.41 \pm 0.49$ \\
\hline
\end{tabular}

Table.4 Interpretations of RULA Action Levels

\begin{tabular}{|c|c|}
\hline Action Level & Interpretation \\
\hline 1 & $\begin{array}{l}\text { Score of } 1-2 \text { indicates that the posture is acceptable if it is not } \\
\text { maintained or repeated for long period of time }\end{array}$ \\
\hline 2 & $\begin{array}{l}\text { Score of 3-4 indicates that further investigation is needed, and } \\
\text { changes may be required }\end{array}$ \\
\hline 3 & $\begin{array}{l}\text { Score of 5-6 indicates that investigation and changes are } \\
\text { required soon }\end{array}$ \\
\hline 4 & $\begin{array}{l}\text { Score of } 7 \text { indicates that investigation and changes are } \\
\text { required immediately }\end{array}$ \\
\hline
\end{tabular}

Source: McAtamney and Corlett

Table.5 SI (Strain Index) score of the respondents in different weaving activities in a cycle time

\begin{tabular}{|l|l|l|l|}
\hline \multirow{2}{*}{ Weaving activities } & \multicolumn{2}{l}{ SI score $(M e a n+$ SD) } & \multirow{2}{*}{ P-value } \\
\cline { 2 - 3 } & Left Hand & \multicolumn{1}{l|}{ Right Hand } & \\
\hline Spinning & $4.91 \pm 1.6$ & $15.63 \pm 4.65$ & $<0.001$ \\
\hline Winding and twisting & $3.93 \pm 2.12$ & $6.10 \pm 3.49$ & $<0.001$ \\
\hline Warping & $2.95 \pm 0.93$ & $4.30 \pm 2.12$ & $<0.001$ \\
\hline Threading the healds & $5.21 \pm 1.66$ & $6.03 \pm 2.39$ & $<0.05$ \\
\hline Threading the reeds & $5.94 \pm 3.15$ & $7.31 \pm 2.63$ & $<0.05$ \\
\hline Setting the warp on the loom & $5.80 \pm 3.36$ & $6.37 \pm 3.46$ & $<0.001$ \\
\hline Preparing the loom for weaving & $5.29 \pm 4.45$ & $10.68 \pm 7.65$ & $<0.05$ \\
\hline Weaving & $34.81 \pm 18.34$ & $46.59 \pm 39.31$ & $<0.001$ \\
\hline
\end{tabular}

$\mathrm{SD}=$ Standard Deviation, Significant at 0.05 percent, significant at 0.001 percent

SI score: <3: safe, between 3 and 5:Uncertain, between 5 and 7:Some risk, > 7: Hazardous 
Fig.1 a) Spinning b) Winding c) Twisting d) Warping e)Threading the healds f)Threading the reeds g)Preparing the loom for weaving $h$ )Setting the warp on the loom i) Weaving

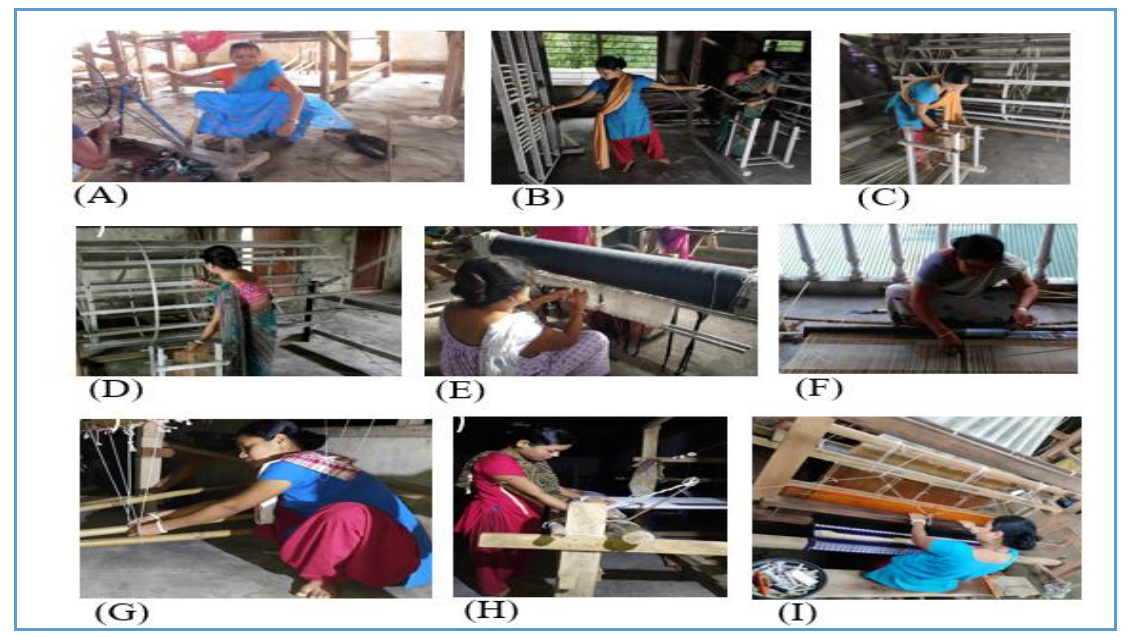

Assessment of SI (strain index) of the workers

Strain index was evaluated to determine the WMSD (work-related musculoskeletal disorder) of elbow, forearm, wrist, and hand in the handloom workers. Table 5 shows that the mean and SD of the strain index score was found highest in the right hand and left hand of the handloom activity weaving with 46.59 \pm 39.31 and $34.81 \pm 18.34$ followed by the right hand of spinning $15.63 \pm 4.65$ and preparing the loom for weaving $10.68 \pm 7.65$. The strain index score of the right-hand was more compared to the left hand in all the handloom activities. The weaving activities in spinning, winding /twisting, setting the warp on the loom and weaving are significantly $(p<0.001)$ different between the left hand and right hand of the workers.

The findings of the study reveal that the handloom weaving process undergoes various activities before weaving. The process starts from spinning to weaving. Although, the workers participated in all the activities the extent of involvement was found high in weaving followed by spinning. The postures adopted by the women workers while undergoing these activities were standing, sitting, and squatting position with awkward posture for a long duration. The RULA score was found high scored 5-6 in most of the activities. Weaving scored the highest with $6.41 \pm 0.49$ which indicates high risk and make changes and improvement in the workstation. The strain index scored highest in the left and right hands for weaving followed by spinning for the left hand. When compared between the left hand and right hand, a higher Strain Index score was found in the right hand due to the constrain of workload and work demand. Musculoskeletal pain increases with length of exposure in occupation (Metgud et al., 2008) if the awkward posture is maintained for a long duration with repetitive tasks and forceful exertion. Thus, improving the workstation and developing tools and equipment according to the anthropometric dimension of the workers would help in reducing the occupational risk and providing maximum efficiency and increased productivity while performing the activities in the weaving process.

In conclusion the preceding result of the study revealed that weaving activities were adopted in awkward postures for a long hour. The 
RULA score was found to be highest in weaving followed by warping and spinning. The strain index score was highest in weaving activity in both the left and right hand. Therefore, an ergonomically equipped workstation would help in reducing the exertion in the handloom activities in the women workers.

\section{Acknowledgments}

I would like to thank all the women weavers who voluntarily participated throughout my research work.

\section{References}

Banerjee, P., and S. Gangopandyay. 2003. A Study on the Prevalence of Upper Extremity Repetitive Strain Injuries among the Handloom Weavers of West Bengal. Journal of Human Ergology. 32: $17-22$

Borah, R. and Kalita, M. 2016. Ergonomic evaluation of weaving activity and ergonomic intervention for drudgery reduction of weaver. Advance Research Journal of Social Science. 7(2): 239-244.

Chantaramanee, N., Taptagaporn, S., and Piriyaprasarth. 2015. The assessment of occupational ergonomic risks of handloom weaving in Northern Thailand. Thammasat International Journal of Science and Technology. 20(4): 29-37.

Choobineh, A., Hosseini, M., Lahmi, M., Jazani, R. K. and Shahnavaz, H. 2007. Musculoskeletal problems in Iranian hand-woven carpet industry: Guidelines for workstation design. Applied Ergonomics. 38: 617-624.

Dewangan, K.N and Sora, K.2015. Job demand and human-machine characteristics on musculoskeletal pain among female weavers in India. Proceedings 19th Triennial Congress of the IEA, Melbourne 9-14 August 2015

Fourth all India handloom census.2019-2020. Office of The Development Commissioner for Handlooms, Ministry of Textiles Government of India.

McAtamney, L. and Corlett, E.N.1993. RULA: a survey method for the investigation of work-related upper limb disorders. Appl. Ergonomics. 24: 91-99.

Metgud, D.C., Khatri, S., Mokashi, M.G. and Saha, P.N. 2008. An ergonomic study of women workers in a woolen textile factory for identification of health related problems. International Journal of Occupational and Environmental Medicine. 12(1): 14-19.

Moore, J.S and Garg, A. 1995. The Strain Index: a proposed method to analyze jobs risk distal upper extremity disorders, American Industrial Hygiene Association Journal. 56(5). 443-458.

Nag, A., Vyas, H. and Nag P.2010. Gender differences, work stressors and musculoskeletal disorders in weaving industries. Industrial Health, 48, 339348.

Pandit, S., Kumar, P. and Chakrabarti, D. 2013. Ergonomic problem prevalent in handloom units of north east India. International Journal of Scientific and Research Publications. 3:1.

\section{How to cite this article:}

Geetashree Bori and Nandita Bhattacharyya. 2020. Postural Assessment of Women Workers Involved in Various Handloom Activities. Int.J.Curr.Microbiol.App.Sci. 9(10): 3585-3591. doi: https://doi.org/10.20546/ijcmas.2020.910.414 